\title{
Revolutionary Learning, Biodiversity, and Transformative Action
}

\author{
PETER MAYO \\ Learning in Social Action: A Contribution to Understanding Informal Education by Griff \\ Foley. London and New York: Zed Books, 1999. 163 pp. \$19.95 (paper). ISBN \\ 1-85649-684-8. \\ Transformative Learning: Educational Vision for the Twenty-First Century by Edmund \\ O'Sullivan. London and New York: Zed Books; Toronto: University of Toronto \\ Press, 1999. 304 pp. \$25.00 (paper). ISBN 1-85649-699-6. \\ Che Guevara, Paulo Freire and the Pedagogy of Revolution by Peter McLaren. Maryland \\ and Oxford, England: Rowman \& Littlefield, 2000. 223 pp. \$22.95 (paper). \\ ISBN 1-800-462-6420.
}

We have been swamped, for quite some time now, by a pernicious discourse in education that emphasizes what is, rather than what should and can be. It is a discourse that, in regarding "the present as definitive of that which is possible," exalts technical-rationality and marketability at the expense of a concern with issues regarding social justice and life-sustaining values. ${ }^{1}$ This discourse is, of course, reflective of the current stage of capitalist reorganization and the misplaced triumphalism of capitalism itself in the wake of the demise of existing socialism marked by the collapse of the Berlin Wall (together, one might add, with such occurrences as the electoral defeat of the Sandinistas in 1990). ${ }^{2}$ In keeping with this climate of resigning oneself to what is, we are swamped by the hegemonic neoliberal ideology and such inanities as posed by those theorists who tell us that we are witnessing the end of ideology and that we need to think/act beyond left and right. Alas, this thinking has also been embraced by parties in government that have historically been socialist, thus testifying to neoliberalism's hegemonic nature. ${ }^{3}$ This scenario has led to widespread cynicism, often bordering on nihilism, regarding attempts to dream of a world that, in Paulo Freire's words, would be "menos feio, menos malvado, menos desumano" [less ugly, less cruel, less inhumane]. ${ }^{4}$ Certain strands of postmodern-

Thanks are due to Paula Allman for her feedback on an earlier draft.

${ }^{1}$ Roger I. Simon regards any genuine project of possibility as refuting this situation: Roger I. Simon, Teaching against the Grain: Texts for a Pedagogy of Possibility (Toronto: OISE Press, 1992), p. 30. Most of the ideas in this introductory section derive from the introduction to my 1999 book: Peter Mayo, Gramsci, Freire and Adult Education: Possibilities for Transformative Action (London: Zed Books, 1999).

${ }^{2}$ See E. Hobsbawm, "The Big Picture: The Death of Neo-Liberalism," Marxism Today (NovemberDecember 1998): 4-8; N. Chomsky with H. Dieterich, "The Pope, Cuba and the Asian Crisis," in Latin America From Colonization to Globalization (Melbourne: Ocean Books, 1999), pp. 106-13.

${ }^{3}$ See, e.g., Hall's critique of New Labour and the so-called Tony Blair project in Stuart Hall, "The Great Moving Nowhere Show," Marxism Today (November-December 1998): 9-14.

${ }^{4}$ Freire, cited in M. Gadotti and C. A. Torres, "Paulo Freire: An Homage," Taboo: The Journal of Culture and Education 11 (1997): 96-101.

Comparative Education Review, vol. 45, no. 1 .

(C) 2001 by the Comparative and International Education Society. All rights reserved. 0010-4086/2001/4501-0006\$02.00 
ism, though highlighting important silences within the grand narratives of Cartesian thought and affirming difference and identity, have contributed to this radical impasse with their ludic mystifications and treatment of subjects "as mere functions of discourse, as entities that float aimlessly in a sea of ever-proliferating signifiers." 5

And yet, I would argue that the scenario of mass impoverishment in various parts of the world caused by the ruthless dismantling of social programs; the everwidening gap between North and South; the concomitant displacement of people from this very same South and Eastern Europe to create a Third World in the First World; the constant rape of the earth for profit; as well as the persistence of structures of oppression in terms of class, gender, race, ethnicity, sexuality, age, and ability/disability, strike me as being among the several reasons why we should still be preoccupied with how and "what we are producing, who it benefits or who it hurts." 6 These are reasons for why we should be concerned with engaging in educational processes that are not meant to consolidate what is but are driven by a vision of what should and can be. ${ }^{7}$

The three books under review are united in an attempt to map out a vision for education that is guided not by what is but by what should and can be. They furnish us with material to dream of a better world and to develop a healthy sense of utopia, characterized by the dismantling of capitalism, conceived of as an essentially exploitative mode of production, and its replacement by more sustainable forms of development, democratic social relations, and the promulgation of mutually sustaining human-earth relations.

All three authors are fully aware of the omissions and myopias that have characterized much of the thinking concerning progressive social transformation that has been a product of the Enlightenment. None of the authors, however, renounces the idea of the need for a grand narrative that enables one to effectively counter the massive global structuring forces of oppression. Echoing the words of Paula Allman, I would daresay that each of the three books, though recognizing transformative action at the local level and providing in-depth discussions of single issues, enables us "to develop a critical understanding of how all of these and other issues link together in a total structure, a human structure, of oppression welded together by the social relations and objectives of capitalism." ${ }^{8}$ All three works are not intended to "facilitate the integration of generations into the logic of the present system" but, on the contrary, conceptualize education as a vehicle for human emancipation and global transformation. ${ }^{9}$ Theirs is, of course, a "big picture."

The three authors differ in their approaches to presenting the big picture. Griff Foley, for instance, provides us with case studies focusing on learning through social

\footnotetext{
${ }^{5}$ See P. Allman and J. Wallis, "Challenging the Postmodern Condition: Radical Adult Education for Critical Intelligence," Adult Learning, Critical Intelligence and Social Change, ed. J. Thompson and M. Mayo (Leicester: NIACE, 1995), pp. 18-33; V. L. Scatamburlo, "The Revolutionary Legacy of Paulo Freire," Taboo: The Journal of Culture and Education 11 (1997): 55-57.

${ }^{6}$ Paulo Freire, Letters to Cristina: Reflections on My Life and Work (London: Routledge, 1996), p. 84.

${ }^{7}$ The entire paragraph has been extracted, with modification, from Mayo, Gramsci, Freire and Adult Education, p. 5.

${ }^{8}$ P. Allman, Revolutionary Social Transformation: Democratic Hopes, Political Possibilities and Critical Education (Westport, Conn.: Bergin \& Garvey, 1999), p. 6.

${ }^{9}$ J. Thompson, ed., Adult Education for Change (Kent: Hutchinson, 1980), p. 26.
} 
action at the local level. These contextually specific case studies are, however, welded together by three important sections: $(a)$ the discussion on ideology and discourse leading to a case study; $(b)$ the rich discussion on capitalist reorganization, complemented by a case study on worker resistance; and $(c)$ the concluding chapter that situates this empirical material in the context of some of the larger debates in the adult education literature. The studies are drawn from different contexts: Australia, Brazil (a study that would have been enhanced had there not been an overreliance on just one source), and Zimbabwe.

In contrast, Peter McLaren's book focuses on two figures who have attained iconic status in the discourse on liberation. The focus is not on case studies centering around groups of people but on two of this century's greatest voices of freedom: Ernesto Che Guevara and Paulo Freire. Their impact has extended far beyond the confines of their native Latin America. The image of Che, albeit turned into a commercial icon, like those of Malcolm X and Bob Marley (yet another example of capitalism's ability to appropriate oppositional images and discourses), is associated with a variety of left-wing manifestations worldwide, including, according to Jorge Castañeda, many of the manifestations occurring in $1968 .{ }^{10}$ The Rosarian doctor/ revolutionary is a source of inspiration to several left-wing groups, and his cult has haunted many of those associated with his captivity and execution, leading, in a number of cases, to their own demise. ${ }^{11}$

That this much-loved and often romanticized contradictory figure is given greater treatment than Freire in this book is hardly surprising. ${ }^{12}$ There is a burgeoning literature on Che worldwide. He, nevertheless, rarely features in the literature on education except as part of the background information in books focusing on education in Latin America, especially those books that bring "learning in the context of guerrilla warfare" into the equation when discussing nonformal education. ${ }^{13}$ As far as English language publications go, this is, to my knowledge, the first attempt to focus extensively on Che in a book on education. The same cannot be said of Freire in that books on this remarkable educationist/activist continue to be pro-

${ }^{10}$ For an extensive discussion on the cult of Che Guevara and its impact on the 1968 movements, see the last chap., titled "Morte e Resurrezione" (Death and resurrection) in J. G. Castañeda, Compañero: Vita e morte di Ernesto Che Guevara (Compañero: Life and death of Ernesto Che Guevara) (Milan: Mondadori, 1997). For an evocative account of the invocation of Che's name during massive protests in the wake of a 1994 International Monetary Fund meeting in Madrid, see the penultimate chap. in A. Mattei, Ernesto Che Guevara: Una vita per la libertà (Ernesto Che Guevara: A life for liberty) (Rome: Newton \& Compton Editori, 1997).

${ }^{11}$ See the penultimate chap. 61, "La 'Maledizione' del Che" (The "curse" of Che), in Paco Ignacio Taibo II's detailed Che biography, Senza perdere la tenerezza: Vita e morte di Che Guevara (Without losing one's tenderness: Life and death of Che Guevara) (Milan: Il Saggiatore, 1997). See also Mattei, p. 214.

${ }^{12} \mathrm{P}$. Leistyna reminds us that there was a hard streak in Che Guevara, who presided over executions. Pepi Leistyna, "Avoiding the Tragedy That Awaits Us: Reviving the Spirit(s) of Revolution," in Educational Researcher 29, no. 3 (2000): 34-37. Che's famous dictum was that one needs to be tough without losing one's tenderness. McLaren himself discloses, in a footnote, that at a seminar on Che at the University of California, Los Angeles, he was confronted by a Cuban who stated that Che had executed his father at La Havana. For a detailed and chilling account of Che's direct involvement in the execution of Eutimio Guerra, see chap. 12, titled "Esecuzione" (Execution), in Taibo, p. 150.

${ }^{13}$ The classic example here would be chap. 10, "Popular Education within Revolutionary Guerrilla Warfare," in T. J. La Belle, Nonformal Education in Latin America and the Caribbean: Stability, Reform or Revolution? (New York: Praeger, 1986), pp. 221-50. Indeed, one other classic example is Paulo Freire's most celebrated work, Pedagogy of the Oppressed (New York: Seabury Press, 1970). Che was, of course, one of the figures who served as an important source of inspiration to Freire. 
duced, leading cynics to talk in terms of a "Freire industry" in education. And yet, McLaren's discussion of Freire is one of the most comprehensive I have seen, drawing on a variety of sources, both primary and secondary, and treating the Brazilian's oeuvre comprehensively and holistically. ${ }^{14}$

Both figures represent contexts, mainly so-called Third-World contexts, spanning Latin America, the Caribbean, and Africa (Congo in Che's case and the former Portuguese colonies in the case of Freire). These contexts are appropriately dealt with. McLaren provides detailed accounts of colonial atrocities and popular resistance throughout the ages to more recent times. Through the images, struggles, thoughts, and legacies of Che and Freire, McLaren provides a scathing attack on white "tentacular" capitalism and its ever-present globalizing and colonizing tendencies. This work is very much a grand narrative of anticolonial struggle. ${ }^{15}$

Arguably, the biggest picture of all three is provided by Edmund O'Sullivan. This book is significant, in my view, because it stretches the boundaries of critical pedagogy. It is to be admired for its comprehensiveness and breadth of analysis, drawing on political economy; physics; cosmology; and feminist, antiracist, and indigenous pedagogy. O'Sullivan's analysis of oppression and domination extends beyond the realm of social relations (given adequate and detailed treatment) to that of cosmic relations. In other words, O'Sullivan, together with others, manages to move well beyond the limits of the kind of progressive action that remains immersed within an anthropocentric framework. ${ }^{16}$ In this work, O'Sullivan provides us with a critical approach to pedagogy grounded in a comprehensive history of the universe.

O'Sullivan identifies the ecological dimension as one of the missing features of much of what passes for critical pedagogy:

Probably one of the most prominent omissions in the critical pedagogical approaches to education at this juncture of its formulations is its lack of attention to ecological issues. My major criticism of a critical perspective is their preeminent emphasis on inter-human problems frequently to the detriment of the relations of humans to the wider biotic community and the natural world. The general direction of critical perspectives is towards anthropocentrism. The criticism of anthropocentrism is by no means a reason for dismissal of the vital concerns that critical perspectives pose for contemporary education. These issues must be taken forward and fused into wider biocentric concerns. (Pp. 63-64)

The work of one of the two figures in McLaren's book-Paulo Freire-seems to confirm O'Sullivan's strictures concerning much of the prevalent critical perspectives on education. Freire, whose work is regarded by Henry Giroux as de rigueur for any serious engagement with critical pedagogy, has himself rarely ventured, in

${ }^{14}$ Apart from edited vols., one comes across a number of book-length, single-authored studies in English focusing exclusively on Freire. These include P. V. Taylor, The Texts of Paulo Freire (Buckingham: Open University Press, 1993); J. Elias, Paulo Freire: Pedagogue of Liberation (Malabar, Fla.: Krieger, 1994); M. Gadotti, Reading Paulo Freire: His Life and Work (Albany, N.Y.: SUNY Press, 1994); and P. Roberts, Education, Literacy, and Humanization: Exploring the Work of Paulo Freire (Westport, Conn.: Bergin \& Garvey, 2000).

${ }^{15}$ The term "tentacular" is taken from P. McLaren, "The Educational Researcher as Critical Social Agent," in Multicultural Research: A Reflective Engagement with Race, Class, Gender and Sexual Orientation, ed. C. A. Grant (Philadelphia: Falmer, 1999), pp. 168-99.

${ }^{16}$ See F. Gutierrez and C. Prado, Ecopedagogia e cittadinanza planetaria (Ecopedagogy and planetary citizenship) (Bologna: EMI, 2000); and M. Hart, Working and Educating for Life: Feminist and International Perspectives on Adult Education (London: Routledge, 1992). 
his own analysis, beyond the anthropocentric framework. ${ }^{17}$ It is, however, heartening to see the institute that bears his name, which he helped found with Moacir Gadotti, give a place to biocentric concerns in its work. ${ }^{18}$ It is equally heartening to see one other book, in the triad under review, focusing on these issues. In fact, the second case study in Foley's book focuses on learning in a green campaign. It describes and analyzes the efforts of settlers in "a 700-hectare remnant of what was a 75,000 hectare rainforest on the east coast of Australia" to "develop a self-sufficient, ecologically sound and often communal way of life" (p. 27).

All three works pay sufficient attention to political economy. The Foley and McLaren books, in particular, devote great importance to this domain. The two authors exhort readers, in an attempt to deepen their understanding of the present historical conjuncture, to develop a political economy approach. They both would like to see a greater presence of such an approach in the literature claiming to provide critical perspectives on education and, more specifically in Foley's case, adult education. In its multivaried analysis, O'Sullivan's book draws on Marxian concepts concerning class but is, understandably, very scathing in its critique of actually existing socialism's environmental record. The other two books are likewise critical of Soviet-style communism but are avowedly historical materialist in their approaches. Together with a few other recent books in English, they are helping to bring about a return to historical materialist analysis in education. ${ }^{19}$ In fact, Griff Foley concludes his book with a plea for a turn to historical materialism in the critical adult education discourse. His case studies relate to diverse contexts and identify pockets of resistance and collective action in different parts of the globe. The case studies also stress the intersections between class and other forms of oppression, all of which connect with white capitalism and its ever-globalizing nature (white imperialism, in the case of Zimbabwe; multinationals, in the case of Brazil, etc.). This is intended to furnish us with material that can provide signposts for transformative action within a historical materialist framework.

Ellen Meiksins Wood defines historical materialism thus: "Historical materialism begins with the simple proposition that human beings obtain the material conditions of their existence through specific and historically variable relationships with nature and with other human beings. The most basic fact about any form of social organisation is the nature of those relationships, the specific ways in which any given society goes about providing the material conditions of existence." ${ }^{20}$

${ }^{17}$ In a conversation with Carlos Alberto Torres, Henry Giroux states, "I think that anyone who took up that field, in some way, had to begin with him (Freire) whether they liked him or not"; cited in C. A. Torres, Education, Power, and Personal Biography: Dialogues with Critical Educators (New York: Routledge, 1998), pp. 129-54; S. Aronowitz, "Introduction," in Paulo Freire, Pedagogy of Freedom: Ethics, Democracy and Civic Courage (Lanham, Md.: Rowman \& Littlefield, 1998), p. 11.

${ }^{18}$ The Instituto Paulo Freire (IPF) has a program in ecopedagogy meant to promote the construction of a planetary citizenship. It is working toward the creation of an earth charter (carta da terra) along the lines of the Universal Declaration of Human Rights; Instituto Paulo Freire, Institutional Curriculum (Curriculo Institucional) 2000: Project, Profile and Trajectory (Projeto, Perfil e Percurso) (São Paulo: Instituto Paulo Freire, 2000), pp. 11-12.

${ }^{19}$ See, e.g., D. W. Livingstone, The Education-Jobs Gap: Underemployment or Economic Democracy (Boulder, Colo.: Westview, 1999); Allman (n. 8 above); F. Youngman, The Political Economy of Adult Education and Development (London: Zed Books, 2000).

${ }^{20}$ E. Meiksins Wood, "The Communist Manifesto 150 Years Later," in K. Marx and F. Engels, The Communist Manifesto (New York: Monthly Review Press, 1998), p. 100. 
As McLaren and others have been arguing elsewhere, Marxist theory has been hastily dismissed as passé and has been supplanted, in progressive academic discourse, by a less threatening and often ludic body of theorizing-postmodern theory. McLaren and Ramin Farahmandpur echo the words of Andy Green, who argues that such a theory smacks of an "individualistic educational consumerism" that bears affinities with the New Right's free market ideology. ${ }^{21}$ I would go along with McLaren and Foley in stating that the huge body of historical materialist analysis can furnish us with the necessary conceptual tools and basic elements for a critical understanding of capitalism and the way it impinges on different aspects of people's lives. These tools of analysis also provide us with the means to recognize the present stage of capitalist restructuring for what it is. The intensification of the process of globalization (capitalism has always been global) constitutes the means whereby capitalism organizes itself to counter the tendency of the rate of profit to fall, owing to the "crises of overproduction." ${ }^{22}$ This point is well illustrated in Foley's rich discussion on adult education and capitalist reorganization (chap. 5) and his account of the way miners resisted management's manipulative strategies, for the purpose of workplace restructuring, in a particular Australian context.

None of the three authors, of course, subscribes to a reductionist view of oppression; certainly not O'Sullivan. Unlike McLaren and Foley, he does not come across as someone who subscribes to a historical materialist viewpoint. While class oppression is of great concern to all three writers, they project a much broader scenario of oppression informed by insights deriving from feminist, antiracist, and indigenous praxes. Theirs is quite a broad vision of social change, a vision that reflects a consciousness of difference (including biodifference) but that is, nevertheless, an integrative one that explores the connections and intersections between different forms of oppression. This integrative vision makes the struggle against capitalist relations of production and the uncritical inculcation of market values, as opposed to life-centered values, a very important rallying point. ${ }^{23}$

Given this scenario, we might ask, Where does the contemporary relevance of such a historical figure as Che lie? In McLaren's work, the legacy of Che is to be found in the struggle of the Zapatistas in Chiapas - the struggle assumed by and on behalf of the "wretched of the earth," the indigenous peasant communities in this area of Mexico. This struggle was officially brought to the world's attention with the capture of San Cristobal de Las Casas on January 1, 1994, the date that marked the coming-into-effect of the North American Free Trade Agreement (NAFTA), an

${ }^{21}$ A. Green, "Postmodernism and State Education," Journal of Educational Policy 91, no. 1 (1994): 67-83, cited in P. McLaren and Ramin Farahmandpur, "Reconsidering Marx in Post-Marxist Times: A Requiem for Postmodernism," Educational Researcher 29, no. 3 (2000): 25-33, esp. 31; See also Allman and Wallis (n. 5 above).

22 "The need of a constantly expanding market for its products chases the bourgeoisie over the whole surface of the globe. It must nestle everywhere, settle everywhere, establish connections everywhere. The bourgeoisie has through its exploitation of the world-market given a cosmopolitan character to production and consumption in every country. To the great chagrin of reactionists, it has drawn from under the feet of industry the national ground on which it stood"; Marx and Engels, pp. 7-8.

${ }^{23} \mathrm{On}$ this issue see A. Miles, Integrative Feminisms: Building Global Visions, 1960s-1990s (London: Routledge, 1996), and "Learning from the Women's Movement in the Neo-Liberal Period," in Learning for Life: Canadian Readings in Adult Education, ed. S. M. Scott, B. Spencer, and A. Thomas (Toronto: Thompson Educational Publishing, Inc., 1998), pp. 250-58. 
agreement that inexorably condemned to starvation the southern peasants, the majority of whom are indigenous. ${ }^{24}$

Needless to say, McLaren dwells at length on the struggles in Chiapas, providing detailed accounts of events in the region that testify to his knowledge of the issues involved, born out of his own commitment to the Zapatista cause, a commitment manifested in many of his other writings. ${ }^{25}$ Prior to the emergence of the Zapatistas, it seemed that the guerrillero legacy of Che was just about over in the age, characterized by concertacion, when guerrilla groups began to lay down their arms and take on a different role. The image of Che, however, looms large over any specific campesino struggle in Latin America and, by association, over any project related to popular education. I would assume that Che's image also looms large over the struggle involving another movement of indigenous people in Latin America, namely, the movement of landless peasants known as the Movimento Trabalhadores Rurais dos Sem Terra (MST). Marx and Guevara feature prominently in the talk around socialist values occurring within the MST's education sector. ${ }^{26}$ The MST's extensive program includes courses carried out within the various landless peasants' encampments, the running of primary schools (around 900, catering to 85,000 children) and teachertraining programs. ${ }^{27}$ This is a movement that captured Freire's imagination toward the end of his life and that, surprisingly, does not figure into McLaren's otherwise rich account in this book.

Accounts of the struggles of indigenous peoples in Latin America and elsewhere forcefully drive home the point concerning the way their "web of life," to use O'Sullivan's term, has been destroyed throughout the centuries by Western colonialism, a rapacious process that extricates human beings from their life-sustaining ecological milieu. Echoing Thomas Berry, O'Sullivan underscores the point that we have much to learn from indigenous people with respect to living in communion (a key term in O'Sullivan's account) with the rest of the cosmos- to be part of what many a visionary poet has celebrated and what Samuel Taylor Coleridge, to mention one prominent poet, calls the "one life" in his "Eolian Harp."

The connection between Che's legacy for indigenous struggles in Latin America and elsewhere (established by McLaren in his book), the ecological concerns in the Terrania Creek Campaign (in Foley's book), and the major ecological concerns that are at the heart of O'Sullivan's work cannot be missed. What emerges from these accounts is the need for a process of transformative learning along the lines of what Freire has called "unity in diversity" with the concept of diversity taking on the broad meaning conveyed by O'Sullivan in his educational vision for the twenty-

24 P. Cacucci, “Adesso basta, torniamo indietro" (Enough, let's go back), in Io Marcos: Il Nuovo Zapata racconta (I, Marcos: The new Zapata narrates), ed. M. Duran de Huerta, 6th ed. (Milan: Feltrinelli, 1998), pp. 5-11.

${ }^{25}$ C. Borg, P. Mayo, and R. G. Sultana, "Revolution and Reality: An Interview with Peter McLaren," in Curriculum: Towards New Identities, ed. W. Pinar (New York: Garland, 1997), pp. 355-76.

${ }^{26}$ L. Kane, "Popular Education and the Landless People's Movement in Brazil (MST)," Studies in the Education of Adults 32, no. 1 (2000): 36-50.

${ }^{27}$ Ibid., pp. 40-43. For another account of educational work within the MST, particularly the work of Gelsa Knijnik, see the final chapter in D. Coben, Radical Heroes: Gramsci, Freire and the Politics of Adult Education (New York: Garland, 1998). 
first century. ${ }^{28}$ It is an "ecozoic" vision, characterized by our connectedness to the ecosystem that sustains us, as opposed to the current terminal Cenozoic state, exemplified by the technical-industrial values of Western Eurocentric culture. One might perhaps speak of "unity in biodiversity," though "unity" might be regarded as too suffocating a term.

As an important corrective to what has been regarded as the totalizing nature of the liberating narratives of modernity, we have been exposed to the idea that organizations, which have traditionally been associated with subaltern groups, must "be renewed from top to bottom and ... urgently connect with new causes and new movements based on feminism, anti-racism, ecology, to reconnect with the general interest," to quote John McIlroy's words, which re-echoed those of Raymond Williams. ${ }^{29}$ Recognition of difference is crucial if transformative action is to be effective. We should, however, heed the Croatian scholar, Pedrag Matvejevic, who joins others in warning against the excesses of identity politics: "we have become used to respecting differences but there are also differences that are ends in themselves, being very particularistic, and that destroy forms of solidarity. . . . One must bear in mind the difference between the identity of being [identità dell'essere] and the identity of doing [identità del fare]." 30

In remaining within the boundaries of the former, one is contributing to a process of fragmentation. In making the effort to cross these boundaries and to engage in the latter process, one would be engaging in the sort of integrative process of transformative action necessary to combat oppression in its systemic global forms. Forms of solidarity (solidarity with humans and other species) in biodiversity are necessary. As Nawal El Saadawi reminds us in her critique of postmodernism, the tendency toward homogenizing and unifying the world into a single market is complemented by a fragmentation of power at the bottom-a postmodern version of divide and rule. She elaborates: "The movement towards a global culture is therefore not contradicted by this postmodern tendency towards cultural fragmentation and identity struggles. They are two faces of the same coin. To unify power, economic, or cultural, at the top it is necessary to fragment power at the bottom. To maintain the global economy of the few, of the multinationals, unification must exist at the top, amongst the few, the very few." 31

${ }^{28}$ Paulo Freire, "A Response," in Mentoring the Mentor: A Critical Dialogue with Paulo Freire, ed. P. Freire with J. W. Fraser, D. Macedo, T. McKinnon, and W. T. Stokes (New York: Peter Lang, 1997) p. 310.

${ }^{29}$ J. Mcllroy, "Community, Labour and Raymond Williams," Adults Learning 14, no. 10 (1993): 277; R. Williams, Towards 2000 (London: Chatto \& Windus, 1983).

${ }^{30}$ My literal translation from Pedrag Matvejevic's address, in Italian, to the Civil Forum EuroMed held in Naples in 1997. Laboratorio Mediterraneo, Obiettivi e mezzi per il partenariato Euromediterraneo: Il forum civile Euromed (Objectives and means for the Euro-Mediterranean partnership: The civil forum Euromed) (Napoli: Magma, 1997), pp. 122-23. Point reproduced from P. Mayo, "Globalization, Postcolonialism and Identity: The Role of Education in the Mediterranean" (paper delivered at the international course Redefining Cultural Identities: The Multicultural Contexts of the Central European and Mediterranean Regions, Dubrovnik, May 2000), which will be published in the book containing the papers delivered at this course, edited by Nada Svob Dokic for the Culturelinks program.

${ }^{31}$ Nawal El Saadawi, "Why Keep Asking Me about My Identity?" The Nawal El Saadawi Reader (London: Zed Books, 1997), pp. 121-22. This entire section on El Saadawi's ideas is reproduced from Peter Mayo, "Globalization, Postcolonialism and Identity: The Role of Education in the Mediterranean" (paper delivered at the international course Redefining Cultural Identities: The Multicultural Contexts of the 
Given this scenario, the integral form of development called for by O'Sullivan and the integrative process of transformative politics meant to supplant capitalist relations of production and planetary exploitation, called for by all three authors, need to be underscored. We ignore such calls at our peril!

Central European and Mediterranean Regions, Dubrovnik, May 2000), which will be published in the book containing the papers delivered at this course, edited by Nada Svob Dokic for the Culturelinks program. 